\title{
Plasmid-mediate transfer of FLO1 into industrial Saccharomyces cerevisiae PE-2 strain creates a strain useful for repeat-batch fermentations involving flocculation-sedimentation
}

\author{
Daniel G. Gomes, Pedro M.R. Guimarães, Francisco B. Pereira, José A. Teixeira, Lucília Domingues* \\ IBB - Institute for Biotechnology and Bioengineering, Centre of Biological Engineering, Universidade do Minho, Campus de Gualtar, $4710-057$ Braga, Portugal
}

\section{A R T I C L E I N F O}

\section{Article history:}

Received 19 July 2011

Received in revised form 4 November 2011

Accepted 16 December 2011

Available online 24 December 2011

\section{Keywords:}

Yeast flocculation

VHG bio-ethanol production

Repeat-batch operation

Industrial Saccharomyces cerevisiae strains

\begin{abstract}
A B S T R A C T
The flocculation gene FLO1 was transferred into the robust industrial strain Saccharomyces cerevisiae PE-2 by the lithium acetate method. The recombinant strain showed a fermentation performance similar to that of the parental strain. In 10 repeat-batch cultivations in VHG medium with $345 \mathrm{~g}$ glucose/L and cell recycling by flocculation-sedimentation, an average final ethanol concentration of $142 \mathrm{~g} / \mathrm{L}$ and an ethanol productivity of $2.86 \mathrm{~g} / \mathrm{L} / \mathrm{h}$ were achieved. Due to the flocculent nature of the recombinant strain it is possible to reduce the ethanol production cost because of lower centrifugation and distillation costs.
\end{abstract}

(c) 2011 Elsevier Ltd. All rights reserved.

\section{Introduction}

Bio-ethanol fermentation can be improved by media and process optimization and selection of robust microorganisms (Pereira et al., 2010a,b). One of the process strategies currently applied in the fermentation industry is very high gravity (VHG) technology. Compared to conventional fermentations, this approach decreases process water requirements and increases overall plant productivity and final ethanol concentrations (usually above $15 \%, v / v$ ), and thus allows considerable savings in energy for distillation ( $\mathrm{Li}$ et al., 2009). However, high osmotic stress and ethanol inhibition affect the microorganism and result in incomplete fermentations. Saccharomyces cerevisiae strains are the most frequently used microorganisms for large-scale industrial bio-ethanol fermentations due to their ability to ferment a wide range of sugars and to deal with the harmful VHG stresses (Bai et al., 2008). S. cerevisiae CA1185 and PE-2 are industrial strains exhibiting high fermentation performance and stress tolerance under VHG conditions (Pereira et al., 2011). PE-2, isolated from a Brazilian sugar cane-to-ethanol distillery and now intensively used for bio-ethanol production in Brazil, consumed 330 g glucose/L achieving 19.2\% (v/ v) ethanol, using a VHG optimized medium (Pereira et al., 2010a).

\footnotetext{
* Corresponding author. Tel.: +351253 604402; fax: +351253678986.

E-mail addresses: dgg.ebiol@gmail.com (D.G. Gomes), pmrguimaraes@gmail. com (P.M.R. Guimarães), franciscopereira@deb.uminho.pt (F.B. Pereira), jateixeir a@deb.uminho.pt (J.A. Teixeira), luciliad@deb.uminho.pt (L. Domingues).
}

The application of a repeat-batch system with yeast recycling achieves high ethanol productivities (Choi et al., 2009; Li et al., 2009; Ma et al., 2009); however, the need for separating the fermented medium from cells at the end of each batch by filtration or centrifugation (Bai et al., 2008; Sakurai et al., 2000) makes the process expensive. A yeast flocculation-sedimentation process would appear to be able to reduce the cost of the repeat-batch process (Li et al., 2009).

Flocculation is already utilized in a variety of applications such as winemaking (Govender et al., 2010), brewing (Van Mulders et al., 2010) or wastewater treatment (Liu et al., 2009). Wang et al. (2008) transferred a vector harboring the FLO1 gene into S. cerevisiae and Verstrepen et al. (2001) and Zhao et al. (in press) integrated the gene into the yeast's genome to introduce a flocculation phenotype. FLO1 is the most studied gene related to flocculation (Russell et al., 1980). It encodes a large flocculation protein rich in Ser/Thr amino acids (Watari et al., 1994) and when the protein is incorporated into the cell wall, its $\mathrm{N}$-terminal part has the capacity to selectively bind mannose-sugars present on the wall of other cells (Bidard et al., 1995). The binding efficiency depends on several factors such as $\mathrm{pH}$, temperature or the amount of specific components (e.g. cations, sugars, oxygen, ethanol) (Soares, 2011).

In the present work, FLO1-mediate flocculation capacity was introduced into the robust industrial strain, $S$. cerevisiae PE-2, and the recombinant strain was exploited in a VHG repeat-batch system. 


\section{Methods}

\subsection{Yeasts}

S. cerevisiae PE-2 (Basso et al., 2008) was maintained at $4{ }^{\circ} \mathrm{C}$ on YPD [1\% $(\mathrm{w} / \mathrm{v})$ yeast extract, $2 \%(\mathrm{w} / \mathrm{v})$ bactopeptone, $2 \%(\mathrm{w} / \mathrm{v})$ glucose and $2 \%(\mathrm{w} / \mathrm{v})$ agar].

\subsection{Construction of flocculent strains}

\subsubsection{Plasmid construction}

Plasmid pET13.1, an 11.6-kb shuttle vector that contains sequences from plasmid pBR322 as well as the $2 \mu$ origin of replication for $S$. cerevisiae, the yeast gene LEU2 and two copies of the yeast copper resistance gene CUP1 (Henderson et al., 1985; Penttilä et al., 1987) was used as cloning vector. The restriction site HindIII in pET13.1 was used to introduce a cassette consisting of the PGK promoter and terminator. The pET13.1 with the HindIIIPGK cassette was named pLD6. The FLO1 gene with the ADH1 promoter and terminator was obtained from the plasmid pBR-ADH1-FLO1 (Watari et al., 1994) by isolation of the corresponding 6.5-kb fragment after digestion with restriction enzyme BamHI. Plasmid pLD7 was obtained by insertion of the 6.5-kb FLO1 fragment into the BamHI restriction site of pLD6.

\subsubsection{Yeast transformation and selection of flocculent transformants}

Standard recombinant DNA methods were used. Enzymes were used as recommended by manufacturers. Escherichia coli was transformed by electroporation according to protocols from Bio-Rad. DNA plasmid isolation from the recombinant yeast strain was done according to Hoffman and Winston (1987). Vector pLD7 was replicated and isolated from $E$. coli cultures and introduced into PE-2 using the lithium acetate method (Gietz et al., 1992). The selection of transformants was made on NEP agar plates $(\mathrm{g} / \mathrm{L})(2$, $\mathrm{MgSO}_{4} \cdot 7 \mathrm{H}_{2} \mathrm{O} ; 2,\left(\mathrm{NH}_{4}\right)_{2} \mathrm{SO}_{4} ; 3, \mathrm{KH}_{2} \mathrm{PO}_{4} ; 0.25, \mathrm{CaCl}_{2} \cdot 2 \mathrm{H}_{2} \mathrm{O} ; 2$, yeast extract; 3, peptone; 40, glucose; 20, agar) (Henderson et al., 1985) supplemented with $1.5 \mathrm{mM} \mathrm{CuSO}_{4}$ as selective marker. After $3 \mathrm{~d}$ of incubation at $30^{\circ} \mathrm{C}$, cells from 28 colonies with a diameter larger than $1.5 \mathrm{~mm}$ were transferred into test tubes containing $5 \mathrm{~mL}$ of YPD medium (1\% yeast extract, $2 \%$ peptone, $2 \%$ glucose) supplemented with $1.5 \mathrm{mM} \mathrm{CuSO}_{4}$. The tubes were incubated at $30{ }^{\circ} \mathrm{C}$ with $180 \mathrm{rpm}$ for $20 \mathrm{~h}$. Transformants that showed a flocculation phenotype were spread on NEP agar plates supplemented with $1.5 \mathrm{mM} \mathrm{CuSO}_{4}$, allowed to grow at $30^{\circ} \mathrm{C}$ for $3 \mathrm{~d}$ and then stored at $4{ }^{\circ} \mathrm{C}$.

\subsection{Media and fermentations}

\subsubsection{Inoculum culture}

The yeast for inoculation was grown in Erlenmeyer flasks filled to $40 \%$ of their volume with medium containing $(\mathrm{g} / \mathrm{L}) 50$, glucose; 20 , peptone; and 10 , yeast extract. The medium for recombinant strains also included $1.5 \mathrm{mM} \mathrm{CuSO}_{4}$. After incubation at $30{ }^{\circ} \mathrm{C}$ with $150 \mathrm{rpm}$ for $24 \mathrm{~h}\left(\mathrm{OD}_{600}\right.$ of $\left.4-5\right)$, the cell suspension was aseptically harvested by centrifugation $\left(10 \mathrm{~min}\right.$ at $\left.7500 \times \mathrm{g}, 4^{\circ} \mathrm{C}\right)$ and cells were resuspended in ice-cold $\mathrm{NaCl} 0.9 \%(\mathrm{w} / \mathrm{v})$ solution to $200 \mathrm{mg}$ fresh yeast (FY)/mL. This concentrated cell suspension was mixed with an appropriate culture medium volume to achieve a cell density of about $1.3 \times 10^{8}$ cells $/ \mathrm{mL}$.

\subsubsection{Fermentation media}

Fermentations were performed in a previously optimized VHG medium (Pereira et al., 2010a), consisting of (g/L) 300-380, glucose; 44.3 , corn steep liquor (CSL); 2.3 , urea; $3.8, \mathrm{MgSO}_{4} \cdot 7 \mathrm{H}_{2} \mathrm{O}$; and $0.03, \mathrm{CuSO}_{4} \cdot 5 \mathrm{H}_{2} \mathrm{O}$ (corresponding to $0.12 \mathrm{mM} \mathrm{Cu}^{2+}$ ). The CSL was kindly provided by COPAM (Portugal) and its handling and main composition has been previously reported (Pereira et al., 2010a). The $\mathrm{pH}$ of the medium was adjusted to 4.5 with $1 \mathrm{M} \mathrm{NaOH}$. The medium was aerated by stirring with a magnetic bar (length of $3 \mathrm{~cm}$ ) at $>850 \mathrm{rpm}$ for $20 \mathrm{~min}$ before inoculation to achieve an oxygen concentration of $>95 \%$ saturation.

\subsubsection{Shake-flask fermentations}

Shake-flask fermentations were performed in $100 \mathrm{~mL}$ Erlenmeyer flasks fitted with perforated rubber stoppers with glycerol-filled air-locks to permit $\mathrm{CO}_{2}$ exhaustion while avoiding the entrance of air. The cultures were incubated at $30^{\circ} \mathrm{C}$ with $150 \mathrm{rpm}$ orbital agitation.

\subsubsection{Repeat-batch system in shake-flasks}

Repeat-batch operation was initiated with the inoculation of $11 \mathrm{mg} \mathrm{FY} / \mathrm{mL}$ (approximately $1.3 \times 10^{8}$ cells $/ \mathrm{mL}$ ) into $40 \mathrm{~mL}$ of fermentation medium. At the end of the first fermentation cycle, the yeast cells were allowed to sediment (in a $50 \mathrm{~mL}$ tube) for $10 \mathrm{~min}$ and then a volume of upper liquid, corresponding to $90 \%$ of the working volume, was collected. The remaining liquid containing the majority of the yeast cells was diluted in fresh aerated medium to a final volume of $40 \mathrm{~mL}$. This procedure for biomass recycling was repeated in the following cycles. The progress of fermentation was followed by mass loss (resulting from $\mathrm{CO}_{2}$ production) and samples for analyses were taken at the beginning and end of fermentation. At each time-point, the standard deviation between replicates was less than $6 \%$ of the average value for the $\mathrm{CO}_{2}$ production.

\subsubsection{Repeat-batch system in an air-lift reactor}

Bioreactor fermentations were performed in an air-lift reactor (internal recirculation type through a concentric draft tube with an enlarged degassing zone; made in house) with a working volume of $6.1 \mathrm{~L}$ (Klein et al., 2005). The reactor was equipped with a cooling jacket that allowed the temperature control at $30 \pm 1{ }^{\circ} \mathrm{C}$ and a condenser in the top to avoid ethanol evaporation. Agitation was provided by sterile air entering at the base of the reactor at a flow rate of $0.1 \mathrm{vvm}$. For repeat-batch operation, the yeast biomass was recycled by a flocculation-sedimentation process. At the end of each batch, the aeration was stopped for $15 \mathrm{~min}$, allowing the flocculated cells to sediment at the bottom of the bioreactor. The clarified medium was then removed through the feed/outlet port, leaving a remaining volume of approximately $600 \mathrm{~mL}$ (corresponding to a recycling rate of $10 \%$ ). The aeration was restarted and fresh medium was fed to the bioreactor to start the subsequent fermentation run. This procedure was repeated during ten consecutive batches. Initial batch was inoculated with a $200 \mathrm{mg} \mathrm{FY} / \mathrm{mL}$ suspension to obtain $11 \mathrm{mg} \mathrm{FY} / \mathrm{mL}$ (about $1.3 \times 10^{8}$ cells $/ \mathrm{mL}$ ). Fermentation monitoring was performed using the DNS method (Miller, 1959) for reducing sugars quantification.

\subsection{Analytical procedures}

\subsubsection{Determination of yeast concentration and viability}

For fresh and dry yeast mass determinations, a sample of the fermentation broth $(20 \mathrm{~mL})$ was centrifuged for $10 \mathrm{~min}$ at $4800 \times g\left(4^{\circ} \mathrm{C}\right)$ in a pre-weighed dried tube. The supernatant was completely removed and the tube was dried inside and outside and weighed again to give the fresh yeast (FY) mass. Then, the yeast pellet was washed with $20 \mathrm{~mL}$ of distilled water, centrifuged, dried over-night at $105{ }^{\circ} \mathrm{C}$ and the tube was finally weighed to give the dry yeast (DY) mass. The methylene-blue staining method (Mills, 1941) was used to count viable and non-viable cells using a microscope and improved Neubauer counting chamber. Yeast viability was calculated as the ratio of viable (non-stained) and total cells counts. 
2.4.2. Extracellular compounds - glucose, glycerol and ethanol

A sample of fermentation medium was centrifuged $(10 \mathrm{~min}$, $4800 \times g, 4^{\circ} \mathrm{C}$ ) and the supernatant was stored at $-20^{\circ} \mathrm{C}$. Specified compounds were quantified by HPLC (High-Performance Liquid Chromatography), using a Varian MetaCarb $87 \mathrm{H}$ column eluted at $60{ }^{\circ} \mathrm{C}$ with $0.005 \mathrm{M} \mathrm{H}_{2} \mathrm{SO}_{4}$ at a flow rate of $0.7 \mathrm{~mL} / \mathrm{min}$, and a refractive-index detector.

\subsubsection{Intracellular compounds - trehalose, glycerol and sterols}

After centrifugation $\left(10 \mathrm{~min}\right.$ at $\left.4800 \times \mathrm{g}, 4^{\circ} \mathrm{C}\right)$ the yeast pellet was washed with ice-cold $\mathrm{NaCl} 0.9 \%(\mathrm{w} / \mathrm{v})$ and resuspended in the same solution to a concentration of $200 \mathrm{mg}$ FY/mL. From this suspension, duplicate samples were taken for the determination of trehalose, glycerol and sterols. For trehalose and glycerol determination, $0.5 \mathrm{~mL}$ samples were boiled in a water bath for $5 \mathrm{~min}$ and stored frozen $\left(-20^{\circ} \mathrm{C}\right)$. After thawing, trehalose and glycerol were quantified in the extracts by HPLC using the same conditions as described in Section 2.4.2. Sterols were determined after centrifugation of $0.5 \mathrm{~mL}$ samples $\left(10 \mathrm{~min}\right.$ at $4800 \times \mathrm{g}, 0^{\circ} \mathrm{C}$ ). The supernatant was completely removed and the tubes were subjected to a clean nitrogen flow to expel air from the headspace and stored at $-80^{\circ} \mathrm{C}$. Samples were incubated at $80{ }^{\circ} \mathrm{C}$ for $90 \mathrm{~min}$ with $5 \mathrm{~mL}$ alkaline aqueous ethanol $(3.6 \mathrm{M} \mathrm{KOH}$ in $80 \% \mathrm{v} / \mathrm{v}$ ethanol) in screw-cap tubes. After an extraction process with pentane, the sterol quantification was performed by a spectrophotometric assay using a filipin complex (Sigma F9765) (Rowe et al., 1991). The final concentrations of intracellular metabolites were normalized to yeast dry mass (considering that the dry yeast corresponds to $30 \%$ of the fresh yeast mass).

\subsubsection{Flocculation assay}

Yeast's flocculation capacity was evaluated by a flocculation assay, previously described by Soares et al. (1992), with slight modifications. Briefly, yeast cells were washed twice with $\mathrm{NaCl} 15 \mathrm{~g} / \mathrm{L}$ ( $\mathrm{pH} 3$ ) deflocculating solution and a $25 \mathrm{~mL}$ volume of cell suspension was placed in a $25 \mathrm{~mL}$ graduated cylinder. Then, $1 \mathrm{~mL}$ of $100 \mathrm{mM} \mathrm{CaCl}$, was added to induce flocculation. Samples $(0.2 \mathrm{~mL})$ were taken every $2 \mathrm{~min}$ from the same position in the graduated cylinder and the absorbance was measured at $600 \mathrm{~nm}$. An assay without $\mathrm{CaCl}_{2}$ served as control. Sedimentation profiles were obtained by plotting the percentage of yeast cells in suspension for each sample point.

\subsection{Determination of fermentation parameters}

Ethanol conversion yield was calculated as the ratio of the final ethanol concentration and the initial glucose concentration (1) and was expressed as a percentage (\%) of the theoretical conversion yield, i.e. the yield considering a production of $0.511 \mathrm{~g}$ of ethanol/g of glucose:

$Y_{n}=\frac{\frac{P}{\mathrm{f}, n}_{\mathrm{i}, n}}{0.511} \times 100$ for the cycle $n$

Ethanol productivity was defined as the ratio between final ethanol concentration and fermentation time (2):

$q_{n}=\frac{P_{\mathrm{f}, n}}{t_{\mathrm{f}, n}}$

\section{Results and discussion}

The overall strategy presented on this study consists in two distinct phases: incorporation of the flocculation capacity into industrial S. cerevisiae PE-2 strain; application of one of the transformants in a repeat-batch system where yeast could be recycled by flocculation.

\subsection{Yeast transformation and selection of flocculent transformants}

Of the 28 colonies originally picked from the selection medium, only two (FL20 and FL 21) showed a flocculation phenotype (Supplementary Data, Fig. S1). The two strains harbored plasmid pLD7 (Fig. 1). When grown in YPD without added copper, these transformants lost the flocculation ability after 5 consecutive cultivations. This loss was accompanied by a loss of the plasmid.

\subsection{Fermentation performance of FL20 and FL21}

FL20 and FL21 produced similar amounts of ethanol as the parental strain PE-2 (Table 1). For instance, with an initial glucose concentration of $293 \mathrm{~g} / \mathrm{L}$, PE-2 strain was able to produce $141 \pm 5 \mathrm{~g}$ ethanol/L. With a very similar amount of glucose $(292 \mathrm{~g} / \mathrm{L}), \quad$ FL20 and FL21 strains produced $139 \pm 3$ and $140 \pm 2 \mathrm{~g}$ ethanol/L, respectively. This fact indicates that transformation procedure did not affect their capacity to attain high ethanol concentrations. In terms of ethanol productivity, PE-2 and flocculent strains presented values ranging from 2.34 to $2.63 \mathrm{~g} / \mathrm{L} /$ $\mathrm{h}$ without considerable differences between PE-2 and recombinant strains. Moreover, the $\mathrm{CO}_{2}$ production profiles of the recombinant strains were very similar comparing to those of PE-2 (data not shown). Only slightest differences in the biomass concentrations were detected between strains with values ranging from 8 to $10 \mathrm{~g}(\mathrm{DCW}) / \mathrm{L}$, and no significant differences in the ethanol theoretical yields (90-94\%) were found.

\subsection{Repeat-batch fermentation with flocculent strains in shake-flasks}

The performance of recombinant strain FL20 over 5 cycles is summarized in Table 2 and $\mathrm{CO}_{2}$ profiles are presented in Fig. 2. The $\mathrm{CO}_{2}$ production profiles suggest similar fermentation kinetics and efficiencies during the first 3 cycles. In the 4 th cycle, a reduction in glucose consumption rate was observed (Table 2). A possible explanation may be the reduced viability of the cells in that cycle, meaning less cells fermenting. The reduced viability at the end of the 5th cycle can be explained by the fact that this cycle was prolonged after total glucose exhaustion. In all cycles, except cycle 4, 129-136 g ethanol/L was produced within approximately $47 \mathrm{~h}$ (Table 2) and the final ethanol productivity ranged from 2.71 to $3.24 \mathrm{~g} / \mathrm{L} / \mathrm{h}$. The average ethanol productivity and final ethanol concentrations are identical to those obtained with PE-2 over

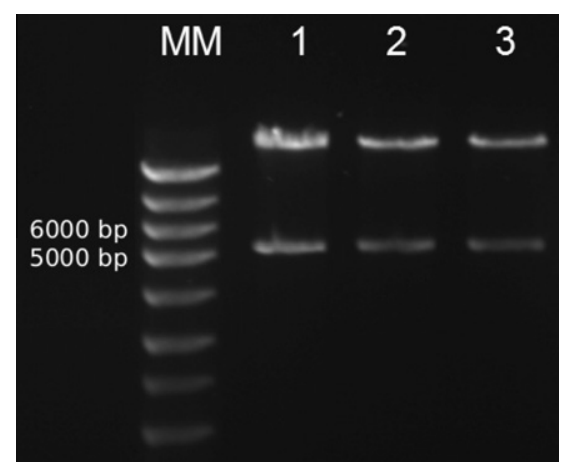

Fig. 1. Agarose gel electrophoresis of digested pLD7 and the plasmid isolated from the recombinant yeasts FL20 and FL21. Lanes: 1 pLD7 used for yeast transformation digested with BamHI; 2, 3 plasmid isolated from S. cerevisiae FL20 and FL21 strains, respectively, and recloned in Escherichia coli TOP10 (Invitrogen) digested with BamHI; MM size marker (NZYDNA Ladder III, NZYTech). 
Table 1

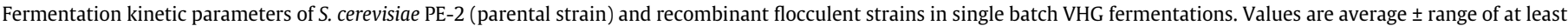
2 independent biological replicates.

\begin{tabular}{|c|c|c|c|c|c|c|}
\hline Strain & Initial glucose $(\mathrm{g} / \mathrm{L})$ & Final ethanol $(\mathrm{g} / \mathrm{L})$ & Residual glucose $(\mathrm{g} / \mathrm{L})$ & Ethanol productivity $(\mathrm{g} / \mathrm{L} / \mathrm{h})$ & Final biomass $\left(\mathrm{g}_{\mathrm{DCW}} / \mathrm{L}\right)$ & Ethanol theoretical yield (\%) \\
\hline PE-2 & $\begin{array}{l}293.4 \pm 0.0 \\
323.0 \pm 0.9\end{array}$ & $\begin{array}{l}141.2 \pm 4.7 \\
149.0 \pm 1.0\end{array}$ & $\begin{array}{l}0.0 \pm 0.0 \\
0.0 \pm 0.0\end{array}$ & $\begin{array}{l}2.34 \pm 0.08 \\
2.37 \pm 0.13\end{array}$ & $\begin{array}{l}8.4 \pm 0.2 \\
9.7 \pm 0.8\end{array}$ & $\begin{array}{l}94 \pm 3 \\
90 \pm 2\end{array}$ \\
\hline FL20 & $\begin{array}{l}291.7 \pm 0.0 \\
321.6 \pm 0.0\end{array}$ & $\begin{array}{l}138.7 \pm 2.7 \\
152.2 \pm 1.5\end{array}$ & $\begin{array}{l}0.9 \pm 0.0 \\
0.0 \pm 0.0\end{array}$ & $\begin{array}{l}2.62 \pm 0.05 \\
2.38 \pm 0.02\end{array}$ & $\begin{array}{r}10.1 \pm 0.2 \\
8.3 \pm 0.3\end{array}$ & $\begin{array}{l}93 \pm 2 \\
93 \pm 1\end{array}$ \\
\hline FL21 & $\begin{array}{l}291.7 \pm 0.0 \\
321.6 \pm 0.0\end{array}$ & $\begin{array}{l}139.5 \pm 1.5 \\
153.4 \pm 2.5\end{array}$ & $\begin{array}{l}1.0 \pm 0.0 \\
1.6 \pm 0.1\end{array}$ & $\begin{array}{l}2.63 \pm 0.03 \\
2.40 \pm 0.03\end{array}$ & $\begin{array}{l}9.9 \pm 0.3 \\
9.9 \pm 0.3\end{array}$ & $\begin{array}{l}94 \pm 1 \\
93 \pm 2\end{array}$ \\
\hline
\end{tabular}

Table 2

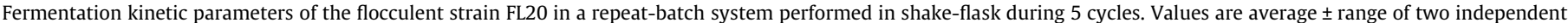
biological replicates.

\begin{tabular}{|c|c|c|c|c|c|c|}
\hline Cycle & Fermentation time $(\mathrm{h})$ & Final ethanol $(\mathrm{g} / \mathrm{L})$ & Residual glucose (g/L) & Ethanol productivity $(\mathrm{g} / \mathrm{L} / \mathrm{h})$ & Final viability (\%) & Ethanol theoretical yield (\%) \\
\hline 1 & 42.0 & $135.9 \pm 1.4$ & $0.0 \pm 0.0$ & $3.24 \pm 0.03$ & $61 \pm 5$ & $80 \pm 1$ \\
\hline 2 & 47.3 & $130.4 \pm 0.2$ & $14.2 \pm 2.4$ & $2.76 \pm 0.00$ & $62 \pm 7$ & $81 \pm 0$ \\
\hline 3 & 47.6 & $128.8 \pm 3.0$ & $0.6 \pm 0.3$ & $2.71 \pm 0.06$ & $54 \pm 3$ & $77 \pm 2$ \\
\hline 4 & 48.0 & $107.8 \pm 2.2$ & $48.0 \pm 0.9$ & $2.25 \pm 0.05$ & $48 \pm 6$ & $67 \pm 1$ \\
\hline 5 & 47.6 & $135.3 \pm 1.6$ & $0.0 \pm 0.0$ & $2.84 \pm 0.03$ & $20 \pm 7$ & $73 \pm 1$ \\
\hline
\end{tabular}

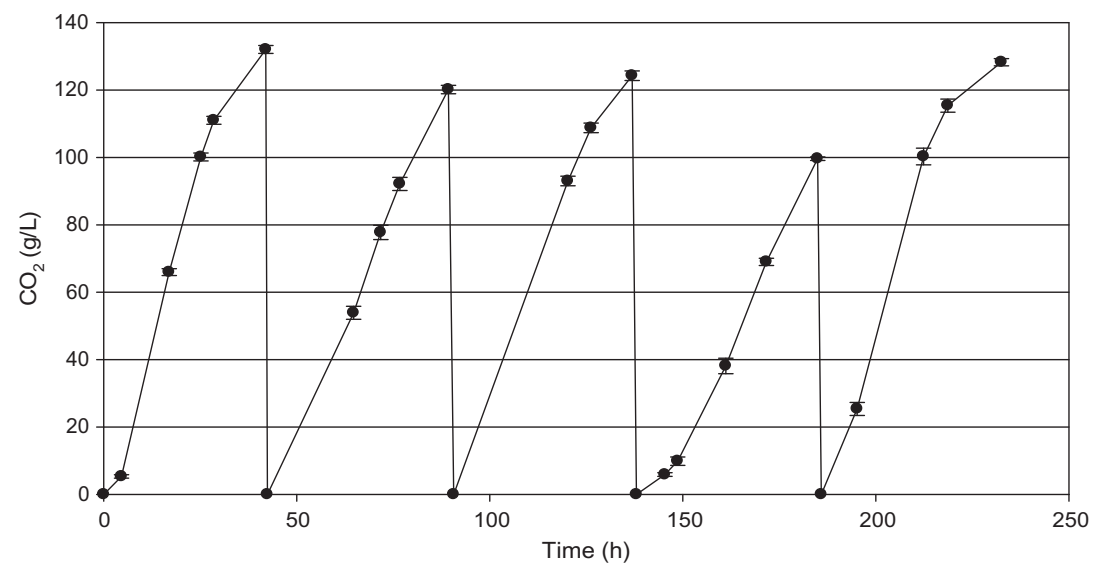

Fig. 2. $\mathrm{CO}_{2}$ production profiles of $S$. cerevisiae FL20 recombinant strain in a repeat-batch system (5 cycles) using a VHG optimized medium (320 g glucose/L).

15 batch cycles with the yeast recovered by centrifugation (Pereira et al., 2012). The final ethanol concentration is however slightly lower than those obtained with a single batch system (73-81\% vs. 90-94\% for the ethanol theoretical yield).

In repeat-batch fermentation with the recombinant FL20 strain, the bio-ethanol production system was simplified due to cells flocculation ability (centrifugation was eliminated with the consequent reduction in capital and maintenance costs and energy consumption) and productivity was increased when comparing to single batch with the same yeast strain. Productivity increase comes from the reduction on the time required for cell growth, therefore increasing initial fermentation rate that is considerably lower for the single-batch systems. In the present work, an average ethanol productivity of $2.38 \mathrm{~g} / \mathrm{L} / \mathrm{h}$ was obtained when FL20 was used in a single batch fermentation ( 322 g glucose/L), this value being smaller than the $2.76 \mathrm{~g} / \mathrm{L} / \mathrm{h}$ obtained for the repeat-batch operation in shake-flasks. Also, yeast populations can become more robust in such type of operation when comparing to single batch system as the inoculum comes from cells that have already been physiologically adapted, in the previous cycle, to the environmental stress of the fermentation culture. In a natural way, cells with higher tolerance to environmental stress will be those that will originate new cells, from one cycle to another (Silva-Filho et al., 2005).

\subsection{Repeat-batch fermentations with FL20 in an air-lift reactor}

Profiles of glucose consumption and ethanol production are illustrated in Fig. 3 and parameters related to yeast performance are presented in Table 3. The fermentation medium was saturated with oxygen before yeast inoculation, but after a few hours, the dissolved oxygen concentration was near zero and remained close to zero throughout the process. A constant fermentation rate during most of the cycles (except 3rd and 10th cycle) was observed with fermentation times between 44 and $48 \mathrm{~h}$. The final ethanol concentration ranged from 135 to $150 \mathrm{~g} / \mathrm{L}$, with an average value of $142 \pm 5 \mathrm{~g} / \mathrm{L}$. During 3 cycles, all the initial glucose was consumed, and residual glucose concentrations for the remaining cycles were 19 to $58 \mathrm{~g} / \mathrm{L}$ (average of $40.5 \pm 14.6 \mathrm{~g} / \mathrm{L}$ ). The theoretical ethanol yield was always higher than $78 \%$, with an average of $86 \%$.

Values for ethanol productivity ranged from 2.00 to $3.31 \mathrm{~g} / \mathrm{L} / \mathrm{h}$ with an average value of $2.86 \mathrm{~g} / \mathrm{L} / \mathrm{h}$, the highest values being obtained for the $1 \mathrm{st}, 4$ th and 8 th cycles. The final biomass concentration showed a considerable variation between cycles ranging from $12.35 \mathrm{~g} / \mathrm{L}$ at the 1 st cycle, to a maximum of $27.66 \mathrm{~g} / \mathrm{L}$ on the 4 th cycle. Differences in cell viability were observed. At the end of the $1 \mathrm{st}$ batch viability was around $80 \%$, but dropped to $54 \%$ at the end of the 2 nd batch. Thereafter, viability increased again and reached $80 \%$, close to the initial levels. These variations were not correlated 


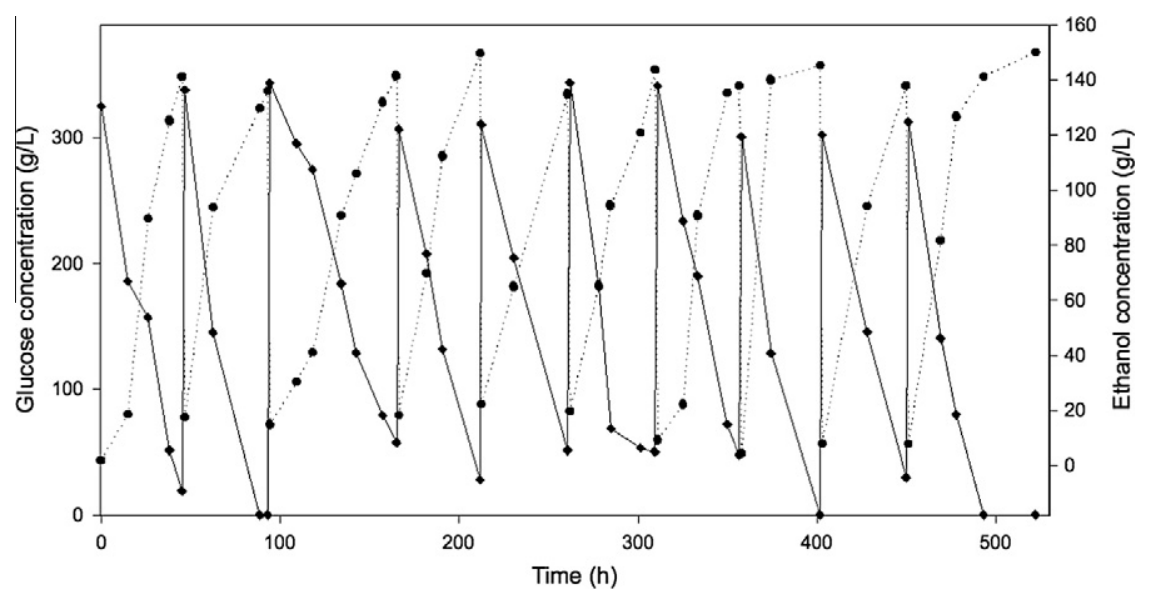

Fig. 3. Profiles of ethanol ( ) and glucose $(\bullet)$ concentration during a succession of 10 repeated batches, performed in an air-lift bioreactor.

Table 3

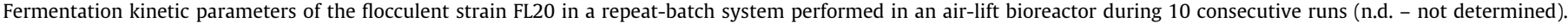

\begin{tabular}{|c|c|c|c|c|c|c|c|c|c|c|c|c|}
\hline$n$ & $t_{\mathrm{f}}(\mathrm{h})$ & $S_{\mathrm{i}}(\mathrm{g} / \mathrm{L})$ & $S_{\mathrm{f}}(\mathrm{g} / \mathrm{L})$ & $P_{\mathrm{f}}(\mathrm{g} / \mathrm{L})$ & $q(\mathrm{~g} / \mathrm{L} / \mathrm{h})$ & $V(\%)$ & $Y(\%)$ & $X_{\mathrm{f}}\left(\mathrm{g}_{\mathrm{DCW}} / \mathrm{L}\right)$ & $\mathrm{pH}$ & $G_{\mathrm{i}}\left(\mathrm{mg} / \mathrm{g}_{\mathrm{DY}}\right)$ & $T\left(\mathrm{mg} / \mathrm{g}_{\mathrm{DY}}\right)$ & $\mathrm{TS}\left(\mathrm{mg} / \mathrm{g}_{\mathrm{DY}}\right)$ \\
\hline 1 & 45.3 & 324.9 & 19.2 & 141.2 & 3.11 & $80.9 \pm 3.47$ & 85 & 12.35 & 4.5 & 5.72 & 91.94 & 12.02 \\
\hline 2 & 46.3 & 337.8 & 0.0 & 136.1 & 2.94 & $54.6 \pm 8.86$ & 79 & n.d. & 5.0 & n.d. & n.d. & 9.91 \\
\hline 3 & 70.7 & 343.2 & 57.4 & 141.3 & 2.00 & $60.2 \pm 4.26$ & 81 & 20.78 & 4.9 & 4.88 & 43.61 & 15.68 \\
\hline 4 & 45.5 & 306.6 & 27.9 & 149.6 & 3.29 & $67.5 \pm 7.21$ & 95 & 27.66 & 4.9 & 10.43 & 41.74 & 8.29 \\
\hline 5 & 48.3 & 310.7 & 51.3 & 134.6 & 2.79 & $62.8 \pm 1.83$ & 85 & 18.68 & 4.8 & 18.15 & 67.34 & 20.89 \\
\hline 6 & 47.5 & 343.7 & 50.2 & 143.7 & 3.03 & $70.9 \pm 5.66$ & 82 & 18.39 & 5.1 & 16.18 & 30.67 & 9.62 \\
\hline 7 & 45.7 & 341.3 & 47.6 & 137.9 & 3.02 & $74.9 \pm 2.80$ & 79 & 12.36 & 4.8 & n.d. & 42.97 & 9.03 \\
\hline 8 & 43.9 & 300.6 & 0.0 & 145.2 & 3.31 & $77.3 \pm 2.54$ & 95 & 21.74 & 6.0 & 15.46 & 33.20 & 12.76 \\
\hline 9 & 46.8 & 302.2 & 29.9 & 137.9 & 2.95 & $79.1 \pm 1.60$ & 89 & 18.00 & 5.1 & 14.08 & 41.88 & 9.03 \\
\hline 10 & 71.1 & 312.5 & 0.0 & 150.0 & 2.11 & $73.6 \pm 3.44$ & 94 & 14.23 & 5.8 & 5.36 & 35.04 & 10.21 \\
\hline
\end{tabular}

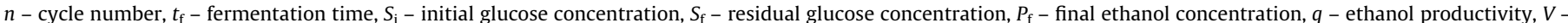

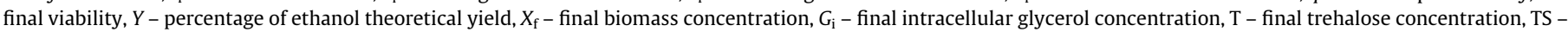
final total sterols concentration.

with the levels of intracellular glycerol, trehalose and total sterols, despite a close association between these compounds and cell viability (Pereira et al., 2011). During the first 3 runs, the final glycerol concentrations were lower than $6 \mathrm{mg} / \mathrm{g}_{\mathrm{DY}}$ and from the 4th cycle on, they ranged from 10 to $18 \mathrm{mg} / \mathrm{g}_{\mathrm{DY}}$. Final trehalose concentrations varied between 30 and $67 \mathrm{mg} / \mathrm{g}_{\mathrm{DY}}$ (average of $42.06 \pm 11.34 \mathrm{mg} / \mathrm{g}_{\mathrm{DY}}$ ), from the $3 \mathrm{rd}$ to the 10 th cycle, which is considerably lower than the amount obtained for the 1 st cycle $\left(91.94 \mathrm{mg} / \mathrm{g}_{\mathrm{DY}}\right)$. The total sterol content in the cells showed a low variability, ranging from 8 to $13 \mathrm{mg} / \mathrm{g}_{\mathrm{DY}}$. Exceptionally, at the end of 3rd and 5th cycles, total sterols content was 15.68 and $20.89 \mathrm{mg} / \mathrm{g}_{\mathrm{DY}}$, respectively.

Industrial strains present a higher robustness relatively to the main stresses that arises from VHG practice (Bai et al., 2008; Pereira et al., 2011). In this study, the yeast viability along the consecutive fermentations was higher than $60 \%$, even with a constant exposition of cells to high ethanol concentrations. Additionally, the levels of intracellular glycerol, trehalose and total sterols were very close to those obtained in a previous work with PE-2 strain in a single batch system (Pereira et al., 2011). The maximum glycerol concentration achieved in the first cycle was $64 \mathrm{mg} / \mathrm{g}_{\mathrm{DY}}$ at $15 \mathrm{~h}$ of fermentation, and at the end of the cycle (ca. $45 \mathrm{~h}$ ) this parameter dropped to $5.72 \mathrm{mg} / \mathrm{g}_{D Y}$ (data not shown). This is consistent with data obtained with the PE-2 strain in a single batch system where a maximum of approximately $42 \mathrm{mg} / \mathrm{g}_{\mathrm{DY}}$ at $12 \mathrm{~h}$ was obtained, decreasing afterwards to approximately $6 \mathrm{mg} / \mathrm{g}_{\mathrm{DY}}$ at $48 \mathrm{~h}$. The final intracellular glycerol concentration for the remaining cycles (with the exception of 3rd and 10th cycles) was considerably higher with an average of $14.86 \mathrm{mg} / \mathrm{g}_{\mathrm{DY}}$. It is possible that the prolonged cell's exposition to a high-solute environment in the 3rd cycle could act as an effective selection process for the more resistant cells in terms of osmotic stress therefore suggesting a possible enhancement of cells robustness over the entire process (Kaino and Takagi, 2008). Relatively to the trehalose levels, they also presented a similar behavior compared with the previously reported data for the PE-2 strain in a single batch system. It was observed that a maximum level of $91.94 \mathrm{mg} / \mathrm{g}_{\mathrm{DY}}$ was achieved around $45-48 \mathrm{~h}$ of fermentation, corresponding to the end of the first cycle (data not shown). The final concentration on the remaining cycles was considerably lower comparatively to the first batch, which could be caused by a higher cell growth that occurs in the first cycle, a relation already reported by Devantier et al. (2005). Other explanation can be the fact that cells from the 1 st cycle came from a pregrowth procedure, being collected at the beginning of stationary growth-phase, the point where storage compounds are maximal. After the 2nd cycle, it was observed a drastically decrease on trehalose accumulation which seems to be associated to a severe drop on cells viability. Finally, concerning the levels of total sterols, no increase was verified along the several cycles despite the reasonable increase registered on yeast cell viability. The association between sterol content of cell membrane and cell viability was widely studied by several authors (e.g. Daum et al., 1998), nevertheless no influence was detected for this parameter on these process conditions.

This work describes and evaluates innovative techniques for bio-ethanol production at different scales, with a particular relevance to the use of flocculation associated to a highly productive repeat-batch fermentation system. The relevance of this comes 
from the fact that, despite the large number of studies that refer the repeat-batch system, the yeast strain used does not correspond to a high-ethanol production strain (Choi et al., 2009; Horiuchi et al., 2000; Kida et al., 1992; Li et al., 2009; Ma et al., 2009; Silva et al., 2010; Wang et al., 2008). In our work, the industrial and high-ethanol tolerant $S$. cerevisiae PE-2 strain was used (Pereira et al., 2010b).

After a succession of ten cycles, FL20 strain produced an average of $142 \pm 5 \mathrm{~g}$ ethanol/L. Choi et al. (2009) using the flocculent S. cerevisiae CHFY0321 achieved an average of only $84.5 \mathrm{~g}$ ethanol/L, using a medium with approximately $177 \mathrm{~g}$ glucose/L and Ma et al. (2009), using the S. cerevisiae ATCC24860, obtained an average ethanol concentration of $77 \mathrm{~g}$ ethanol/L. The closest values to those obtained in the present work were achieved by Li et al. (2009) that, using a medium with $264 \mathrm{~g}$ glucose/L, produced an average of $119.5 \mathrm{~g}$ ethanol/L, which still is $15.6 \%$ lower than our ethanol concentration values. The achievement of these outstanding ethanol concentrations in successive batch fermentations does not follow the most common approach, which consists on enhancing ethanol productivity by using lower initial sugar concentrations and consequently attaining shorter fermentation processes. The present work is focused on the production of very high ethanol concentrations using high-sugar concentration media, which leads to prolonged fermentations, resulting consequently in a decrease on ethanol productivity. Nevertheless, $2.86 \mathrm{~g} / \mathrm{L} / \mathrm{h}$ ethanol productivity was achieved in the described conditions and could still be improved through the reduction of the residual glucose concentration (average of $28.4 \mathrm{~g} / \mathrm{L}$; Table 3 ). By doing this we would not only get an improvement of productivity but also a reduction of the pollution load, associated to sugar content in the fermented broth, and thus an increase of the ethanol conversion yield, which means less amounts of unfermented glucose as well as a reduction in distillation costs.

Bayrock and Ingledew (2001) as well as Wang et al. (2007) also achieved an average ethanol concentration of 132 and $136 \mathrm{~g} / \mathrm{L}$, respectively. Although these values are comparable with the ones obtained in the present work, both works present some serious constraints. In the first one, ethanol productivity was only $1.16 \mathrm{~g} /$ $\mathrm{L} / \mathrm{h}$ (continuous system) and in the second one the fermentation medium had an expensive nutritional supplementation (peptone).

\subsection{Stability of yeast flocculation}

Considering that flocculation was granted through the introduction of a plasmid into the cell, it is possible that this phenotype could suffer specific variations caused by a partial loss of the plasmid. Since selective pressure by copper is necessary for the retention of the plasmid in the culture, but can also have a negative effect on the yeasts' fermentative capability, different $\mathrm{CuSO}_{4}$ concentrations were explored. For the lower copper concentrations ( 0.12 and $0.62 \mathrm{mM}$ ) no effect on the fermentation ability was detected while for the higher copper concentration (1.12 mM) an ethanol production decrease of ca. $3 \%$ was observed. Taking these results into account, we chose to use copper in a lower concentration $(0.12 \mathrm{mM})$ because we wanted to use the previous optimized fermentation medium and we would also select for the flocculent cells by sedimentation. In the presence of this amount of copper, the yeast cultures flocculated consistently during the 10 cycles in the air-lift reactor. Results of flocculation assays performed at 3 different points are presented in Fig. 4. The sedimentation profiles show that cells lost some of their flocculation capacity over time. Yeast cells collected at the end of inoculum culture presented a flocculation rate of $93.7 \%$, what is expectable since the number of cell divisions until then was relatively small and the inoculum culture medium contained the selective marker $\left(1.5 \mathrm{mM} \mathrm{CuSO}_{4}\right)$. For the two other points (5th and 10th cycle), where cells were

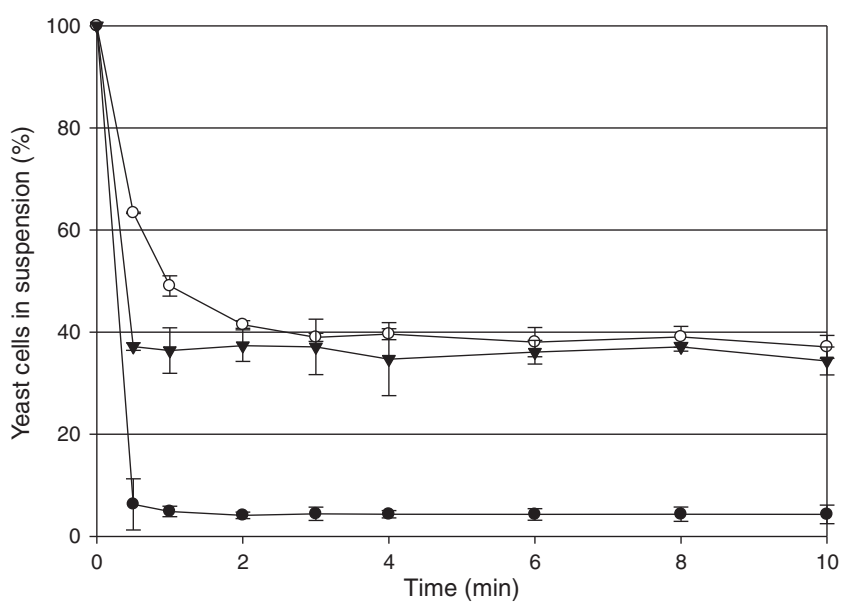

Fig. 4. Sedimentation profiles of FL20 flocculent strain obtained by the method of Soares et al. (1992), at 3 different points of the overall process performed on the airlift: end of inoculum culture $(\bullet)$; middle of 5 th cycle $(\bigcirc)$; end of 10 th cycle $(\mathbf{\nabla})$.

collected from the fermentation medium, the situation was considerably different because cells have been subjected to more cell divisions and the fermentation medium does not have copper in the required concentration to act as selective pressure. Also, we must consider the similarities of these 2 points (5th and 10th cycle) despite the time difference between them. The reason for that could be the low rate of growth after the 4th cycle, as could be seen through the variation of final dry weight (Table 3). Increasing the copper content in the medium could be a good option to reduce plasmid loss, and consequently the variations in flocculation. The use of a $0.62 \mathrm{mM} \mathrm{CuSO}$ concentration would allow for an improvement on flocculation with no effects on fermentation performance. Another solution can be the integration of the gene into the genome of the strain PE-2. Nevertheless, for ten consecutive cycles the yeast flocculation ability was adequate for recovering yeast cells by sedimentation.

\section{Conclusions}

The introduction of a plasmid-borne flocculation gene into industrial strain $S$. cerevisiae PE-2 resulted in a flocculating strain that achieved average ethanol concentrations and final productivities similar to those of the parental strain. The flocculating strain FL20 was studied in a repeated-batch system and applied with high success for 10 consecutive fermentations, with yeast cells recycled over the entire process. An average ethanol concentration of $142 \mathrm{~g} / \mathrm{L}$ was obtained, with a final productivity of $2.86 \mathrm{~g} / \mathrm{L} / \mathrm{h}$. The amounts of specific intracellular metabolites confirmed an efficient response to VHG stress by the flocculent strain, similar to previous reports for the parental strain in single batch fermentation. Since loss of the plasmid and concomitant loss of flocculation capability under non-selective conditions were observed, it might be necessary to stably integrate the flocculation gene into one of the yeast's chromosomes.

\section{Acknowledgements}

The authors thank COPAM - Companhia Portuguesa de Amidos S.A. (Portugal) for kindly providing the CSL, Rosane Schwan (Federal University of Lavras, Brazil) for kindly providing the PE-2 yeast strain and Merja Penttilä (VTT, Finland) for plasmids pET13.1 and pBRADH1-FLO1. The financial support of Fundação para a Ciência e a Tecnologia (FCT), Portugal, is acknowledged. Project ProBioethanol 
PTDC/BIO/66151/2006, grant SFRH/BD/64776/2009 to F.B. Pereira and grant SFRH/BPD/44328/2008 to P.M.R. Guimarães.

\section{Appendix A. Supplementary data}

Supplementary data associated with this article can be found, in the online version, at doi:10.1016/j.biortech.2011.12.089.

\section{References}

Bai, F.W., Anderson, W.A., Moo-Young, M., 2008. Ethanol fermentation technologies from sugar and starch feedstocks. Biotechnol. Adv. 26, 89-105.

Basso, L.C., Amorim, H.V., Oliveira, A.J., Lopes, M.L., 2008. Yeast selection for fuel ethanol production in Brazil. FEMS Yeast Res. 8, 1155-1163.

Bayrock, D.P., Ingledew, W.M., 2001. Application of multistage continuous fermentation for production of fuel alcohol by very-high-gravity fermentation technology. J. Ind. Microbiol. Biotechnol. 27, 87-93.

Bidard, F., Bony, M., Blondin, B., Dequin, S., Barre, P., 1995. The Saccharomyces cerevisiae FLO1 flocculation gene encodes for a cell surface protein. Yeast 11 (9), 809-822.

Choi, G., Kang, H., Moon, S., 2009. Repeated-batch fermentation using flocculent hybrid, Saccharomyces cerevisiae CHFY0321 for efficient production of bioethanol. Appl. Microbiol. Biotechnol. 84, 261-269.

Daum, G., Lees, N.D., Bard, M., Dickson, R., 1998. Biochemistry, cell biology and molecular biology of lipids of Saccharomyces cerevisiae. Yeast 14, 1471-1510.

Devantier, R., Scheithauer, B., Villas-Boas, S.G., Pedersen, S., Olsson, L., 2005. Metabolite profiling for analysis of yeast stress response during very high gravity ethanol fermentations. Biotechnol. Bioeng. 90, 703-714.

Govender, P., Bester, M., Bauer, F.F., 2010. FLO gene-dependent phenotypes in industrial wine yeast strains. Appl. Microbiol. Biotechnol. 86, 931-945.

Gietz, D., Stjean, A., Woods, R.A., Schiestl, R.H., 1992. Improved method for high efficiency transformation of intact yeast cells. Nucleic Acids Res. 20, 1425.

Henderson, R.C.A., Cox, B.S., Tubb, R., 1985. The transformation of brewing yeasts with a plasmid containing the gene for copper resistance. Curr. Genet. 9, 133138.

Hoffman, C.S., Winston, F., 1987. A 10-minute DNA preparation from yeast efficiently releases autonomous plasmids for transformation of Escherichia coli. Gene 57, 267-272.

Horiuchi, J.I., Yamauchi, N., Osugi, M., Kannao, T., Kobayashi, M., Kuriyama, H., 2000. Onion alcohol production by repeated batch process using flocculating yeast. Bioresour. Technol. 75, 153-156.

Kaino, T., Takagi, H., 2008. Gene expression profiles and intracellular contents of stress protectants in Saccharomyces cerevisiae under ethanol and sorbitol stresses. Appl. Microbiol. Biotechnol. 79, 273-283.

Kida, K., Kume, K., Morimura, S., Sonoda, Y., 1992. Repeated-batch fermentation process using a thermo tolerant flocculating yeast constructed by protoplast fusion. J. Ferment. Bioeng. 74, 169-173.

Klein, J., Maia, J., Vicente, A.A., Domingues, L., Teixeira, J.A., Jurascik, M., 2005. Relationships between hydrodynamics and rheology of flocculating yeast suspensions in a high-cell-density airlift bioreactor. Biotechnol. Bioeng. 89, 393-399.

Li, F., Zhao, X.Q., Ge, X.M., Bai, F.W., 2009. An innovative consecutive batch fermentation process for very high gravity ethanol fermentation with selfflocculating yeast. Appl. Microbiol. Biotechnol. 84, 1079-1086.

Liu, X.W., Sheng, G.P., Yu, H.Q., 2009. Physicochemical characteristics of microbial granules. Biotechnol. Adv. 27 (6), 1061-1070.

Ma, K., Wakisaka, M., Sakai, K., Shirai, Y., 2009. Flocculation characteristics of an isolated mutant flocculent Saccharomyces cerevisiae strain and its application for fuel ethanol production from kitchen refuse. Bioresour. Technol. 100, 22892292.

Miller, G.L., 1959. Use of dinitrosalicylic acid reagent for determination of reducing sugar. Anal. Chem. 31, 426-428.

Mills, D.R., 1941. Differential staining of living and dead yeast cells. Food Res. 6 , 361-371.

Penttilä, M.E., Suihko, M.L., Lehtinen, U., Nikkola, M., Knowles, J.K.C., 1987. Construction of brewer's yeasts secreting fungal endo- $\beta$-glucanase. Curr. Genet. 12, 413-420.

Pereira, F.B., Gomes, D.G., Guimarães, P.M.R., Teixeira, J.A., Domingues, L., 2012. Cell recycling during repeated very high gravity bio-ethanol fermentations using the industrial Saccharomyces cerevisiae strain PE-2. Biotechnol. Lett. 34, 45-53.

Pereira, F.B., Guimarães, P.M.R., Teixeira, J.A., Domingues, L., 2011. Robust industrial Saccharomyces cerevisiae strains for very high gravity bio-ethanol fermentations. J Biosci. Bioeng. 112, 130-136.

Pereira, F.B., Guimarães, P.M.R., Teixeira, J.A., Domingues, L., 2010a. Optimization of low-cost medium for very high gravity ethanol fermentations by Saccharomyces cerevisiae using statistical experimental designs. Bioresour. Technol. 101, 78567863.

Pereira, F.B., Guimarães, P.M.R., Teixeira, J.A., Domingues, L., 2010b. Selection of Saccharomyces cerevisiae strains for efficient very high gravity bio-ethanol fermentation processes. Biotechnol. Lett. 32, 1655-1661.

Rowe, S.M., Simpson, W.J., Hammond, J.R.M., 1991. Spectrophotometric assay of yeast sterols using a polyene antibiotic. Lett. Appl. Microbiol. 13, 182-185.

Russell, I., Stewart, G.G., Reader, H.P., Johnston, J.R., Martin, P.A., 1980. Revised nomenclature of genes that control yeast flocculation. J. Inst. Brew. 86, 120 121.

Sakurai, A., Nishida, Y., Saito, H., Sakakibara, M., 2000. Ethanol production by repeated batch culture using yeast cells immobilized within porous cellulose carriers. J. Biosci. Bioeng. 90 (5), 526-529.

Silva-Filho, E.A., dos Santos, S.K.B., Resende, A.M., de Moraes, J.O.F., Morais Jr., M.A Simões, D.A., 2005. Yeast population dynamics of industrial fuel ethanol fermentation process assessed by PCR-fingerprinting. Antonie van Leeuwenkoek 88, 13-23.

Silva, A.C., Guimarães, P.M.R., Teixeira, J.A., Domingues, L., 2010. Fermentation of deproteinized cheese whey powder solutions to ethanol by engineered Saccharomyces cerevisiae: effect of supplementation with corn steep liquor and repeated-batch operation with biomass recycling by flocculation. J. Ind Microbiol. Biotechnol. 37, 973-982.

Soares, E.V., 2011. Flocculation in Saccharomyces cerevisiae: a review. J. Appl Microbiol. 110, 1-18.

Soares, E.V., Teixeira, J.A., Mota, M., 1992. Interaction between flocculent and nonflocculent cells of Saccharomyces cerevisiae. Can. J. Microbiol. 38, 969-974.

Van Mulders, S.E., Ghequire, M., Daenen, L., Verbelen, P.J., Verstrepen, K.J., Delvaux F.R., 2010. Flocculation gene variability in industrial brewer's yeast strains. Appl. Microbiol. Biotechnol. 88, 1321-1331.

Verstrepen, KJ. Michiels, C. Derdelinckx, G., Delvaux, F.R. Winderickx, J., Thevelein, J.M., Bauer, F.F., Pretorius, I.S., 2001. Late fermentation expression of FLO1 in Saccharomyces cerevisiae. J. Am. Soc. Brew. Chem. 59, 69-76.

Wang, F., Shen, W., Rao, Z., Fang, H., Zhan, X., Zhuge, J., 2008. Construction of flocculating yeast for fuel ethanol production. Biotechnol. Lett. 30, 97-102.

Wang, F.Q., Gao, C.J., Yang, C.Y., Xu, P., 2007. Optimization of an ethanol production medium in very high gravity fermentation. Biotechnol. Lett. 29, 233-236.

Watari, J., Takata, Y., Ogawa, M., Sahara, H., Koshino, S., Onnela, M.L., Airaksinen, U., Jaatinen, R., Penttilä, M., Keränen, S., 1994. Molecular cloning and analysis of the yeast flocculation gene FLO1. Yeast 10 (2), 211-225.

Zhao, X.-Q., Li, Q., He, L.-Y., Li, F., Que, W.-W., Bai, F.-W., in press. Exploration of a natural reservoir of flocculating genes from various Saccharomyces cerevisiae strains and improved ethanol fermentation using stable genetically engineered flocculating yeast strains. Process Biochem. 